Urban History, 46, 2 (2019) (C) The Author(s) 2018. This is an Open Access article, distributed under the terms of the Creative Commons Attribution licence (http://creativecommons.org/ licenses/by/4.0/), which permits unrestricted re-use, distribution, and reproduction in any medium, provided the original work is properly cited.

\title{
Football clubs, city images and cultural differentiation: identifying with rivalling Vitesse Arnhem and NEC Nijmegen
}

\author{
JON VERRIET* \\ Sports History Research Group, History Department, Radboud University \\ Nijmegen, Erasmusplein 1, 6525 HT Nijmegen, The Netherlands
}

ABSTRACT: How are deep relationships between city and club identification formed, and are they inevitable? The aim of this article is to provide a historical analysis of the rivalry between two football clubs, Vitesse Arnhem and NEC Nijmegen, explicating their various 'axes of enmity'. Supporters, club officials and observers of these two clubs created and selectively maintained similarities between respective city image and club image. The process of 'othering' influenced both city and club images and helped create oppositional identities. Herein, football identification reflects broader societal needs for a place-based identity, and for a coherent image of both self and other.

\section{Introduction}

The history of sport has proved a fruitful field for research into processes of identification. According to Jeff Hill, the texts and practices of sports represent 'structured habits of thought and behaviour which contribute to our ways of seeing ourselves and others'. ${ }^{1}$ Sports rivalries in particular have received attention from sociologists and historians, as they allow investigations into community bonding and the process of 'othering'.

The cultural relationship between 'place' and a sports club is often considered self-evident. As John Bale has claimed, there is 'little doubt that it is through sport that current manifestations of localism (and regionalism and nationalism) are most visible ${ }^{\prime 2}$ Others have argued that supporting a

* This research is part of the project 'Football clubs and regional identity in Guelders'. It is supported by funding from the province of Guelders. The project has been conceptualized by Professor T.H.G. Verhoeven, who holds the endowed chair for the History of Guelders at Radboud University, and Professor M.E.B. Derks, who holds the chair of sport history at Radboud University. The author would like to thank Dr S.M. Bultman for comments on an earlier version of this article.

1 J. Hill, Sport, Leisure and Culture in Twentieth-Century Britain (Basingstoke, 2002), 2.

2 J. Bale, 'The place of "place" in cultural studies of sports', Progress in Human Geography, 12 (1988), 507-24, at 519. 
football club offers the possibility to 'assert a kind of membership of the city $^{\prime}{ }^{3}$ and that in the past teams have revitalized the distinctiveness of city images, making clubs vehicles for the promotion of 'place'. ${ }^{4}$

But how does such a deep relationship between place and club come into being, and is it truly inevitable? Some ethnographic studies offer valuable insight into how local football cultures engage in the practice of 'continually (re)inscribing and policing physical, as well as, cultural boundaries', ${ }^{5}$ yet such studies generally lack historicity. ${ }^{6}$ Analyses by historians, on the other hand, tend to underrate the relevance of continuing rivalries to club identification, ${ }^{7}$ or fail to engage truly with historical city images, despite the fact that there is often a perceived relationship. ${ }^{8}$

The aim of this article is to provide a historical analysis of the rivalry between two football clubs, Vitesse Arnhem and NEC Nijmegen, explicating the various 'axes of enmity' ${ }^{9}$ between them and examining how the cities' images inform, and are informed by, this rivalry. This will provide insight into the practice of 'othering' in an everyday context, helping to explain fundamental societal hostilities and shed light on why groups preserve or even nurture these hostilities. This article is intended to bring more depth to the field of research concerned with the relationship between city identification and sport identification, which remains underdeveloped. ${ }^{10}$ Furthermore, by envisioning historical football rivalries as part of both cultural history and urban history, it aims at countering the 'ghettoization' of sports history. ${ }^{11}$

${ }^{3}$ R. Holt, 'Football and the urban way of life in nineteenth-century Britain', in J. Mangan (ed.), Pleasure, Profit, Proselytism: British Culture and Sport at Home and Abroad, 1700-1914 (London, 1988), 67-85, at 81.

4 M. Johnes, 'Great Britain', in S. Pope and J. Nauright (eds.), Routledge Companion to Sports History (London and New York, 2010), 444-60, at 450.

${ }^{5}$ S. Lawrence, "'We are the boys from the Black Country"! (Re)Imagining local, regional and spectator identities through fandom at Walsall Football Club', Social \& Cultural Geography, 17 (2016), 282-99, at 289.

${ }^{6}$ E.g. Lawrence, "“We are the boys"'; A. Bairner and P. Shirlow, 'The territorial politics of soccer in Northern Ireland', in G. Armstrong and R. Giulianotti (eds.), Football Cultures and Identities (Basingstoke, 1999), 152-63; H. Hognestad, 'Split loyalties: football is a community business', Soccer \& Society, 13 (2012), 377-91.

7 A. Fløysand and S. Jakobsen, 'Commodification of rural places: a narrative of social fields, rural development, and football', Journal of Rural Studies, 23 (2007), 206-21; N. Phelps, 'Professional football and local identity in the "golden age": Portsmouth in the midtwentieth century', Urban History, 32 (2005), 459-80; H. Shobe and G. Gibson, 'Cascadia rising: soccer, region, and identity', Soccer \& Society, 18 (2017), 1-19; D. Ranc, 'Local politics, identity and football in Paris', Modern \& Contemporary France, 17 (2009), 51-66.

${ }^{8}$ S. Heck, P. Nierhaus and A. Luh, 'Myth or reality of the Revier derby? Schalke 04 versus Borussia Dortmund (1947-2007)', International Journal of the History of Sport, 29 (2012), 203049; S. Gehrmann, 'Football clubs as media of identity in an industrial region. "Schalke" and "Borussia" and the Ruhr area', in idem (ed.), Football and Regional Identity in Europe (Münster and New Brunswick, NJ, 1997), 81-92.

9 S. Dmowski, 'Geographical typology of European football rivalries', Soccer \& Society, 14 (2013), 331-43, at 335.

10 G. Gems, 'The city', in Pope and Nauright (eds.), Routledge Companion, 61.

11 P. Ward, 'Last man picked: do mainstream historians need to play with sports historians?', International Journal of the History of Sport, 30 (2013), 6-13, at 10. 
There are several basic assumptions underlying this article. Both city and club identities are taken to be social constructs. ${ }^{12}$ Identification, then, is viewed as an active process. In both cases, identities are enacted in the utterances and practices of agents inside and outside the club and/or city. ${ }^{13}$ The process of identification 'purifies' one's in-group, encouraging 'othering', or 'the production of difference, competition and rivalry'. ${ }^{14}$

Here, this process of cultural differentiation is examined mainly through the analysis of historical discourse and historical actions. This allows for studying a city (and a football club) not as a physical entity, but as memory, as experience and as symbol. Newspaper articles and (ethnographic) travelogues, as well as some scholarly literature, were used to gauge the popular images of the cities of Arnhem and Nijmegen. The main periodical used was De Gelderlander, the biggest regional newspaper of the Netherlands, which reports on the whole province of Guelders. It has a historically large, fairly representative readership, both from the Nijmegen area and beyond. ${ }^{15}$ For most of the twentieth century, regional newspapers were widely read and, thus, potentially had a meaningful impact on Dutch public opinion. ${ }^{16}$ Additional material was used for examining the football clubs, including, in particular, commemorative books celebrating the history of NEC and Vitesse, as well as other clubs from the Guelders province. Furthermore, the Vitesse archive was consulted - the NEC archive was still under construction. Lastly, informal interviews were held with prominent figures from both fan clubs.

\section{Arnhem and Nijmegen}

The cities of Arnhem and Nijmegen lie close together and are very much alike. Both cities are situated in the east of the Netherlands in the province of Guelders (see Figure 1). Arnhem and Nijmegen's city centres are only 12 miles apart, yet they are separated by two rivers: the Rhine (running through Arnhem) and the Waal (through Nijmegen). In 2016, Nijmegen had 172,000 inhabitants, compared to Arnhem's 154,000, making them the tenth and fourteenth largest cities of the Netherlands.

12 S. Dormans, H. van Houtum and A. Lagendijk, De Verbeelding van de Stad: De Constructie van de Stedelijke Identiteit van Arnhem, Groningen, Maastricht en Tilburg (Utrecht, 2003), 17.

13 M. Derks, 'Sport, Catholicism and regional identity: the making of football culture in a Dutch province', in Gehrmann (ed.), Football and Regional Identity, 143-68, at 146.

$14 \mathrm{H}$. van Houtum and F. van Dam, 'Topophilia or topoporno? Patriotic place attachment in international football derbies', HAGAR, International Social Science Review, 3 (2002), 231-48, at 235.

15 De Gelderlander was supplemented with other popular newspapers, such as the Arnhemse Courant, which had a higher Protestant and slightly wealthier readership. Nederlandse Stichting voor Statistiek, Arnhemsche Courant, Nijmeegs Dagblad, Gelders Dagblad: Samenstelling volgens Sociaal-Economische Kenmerken van de Kring van Abonnees (The Hague, 1961).

16 In 1952, for instance, 96\% of households in the Nijmegen region had a newspaper subscription. CEBUCO, Vademecum van een Aantal Markanalytische Gegevens van de Afgeronde Provincie Gelderland (The Hague, 1953), 10. 


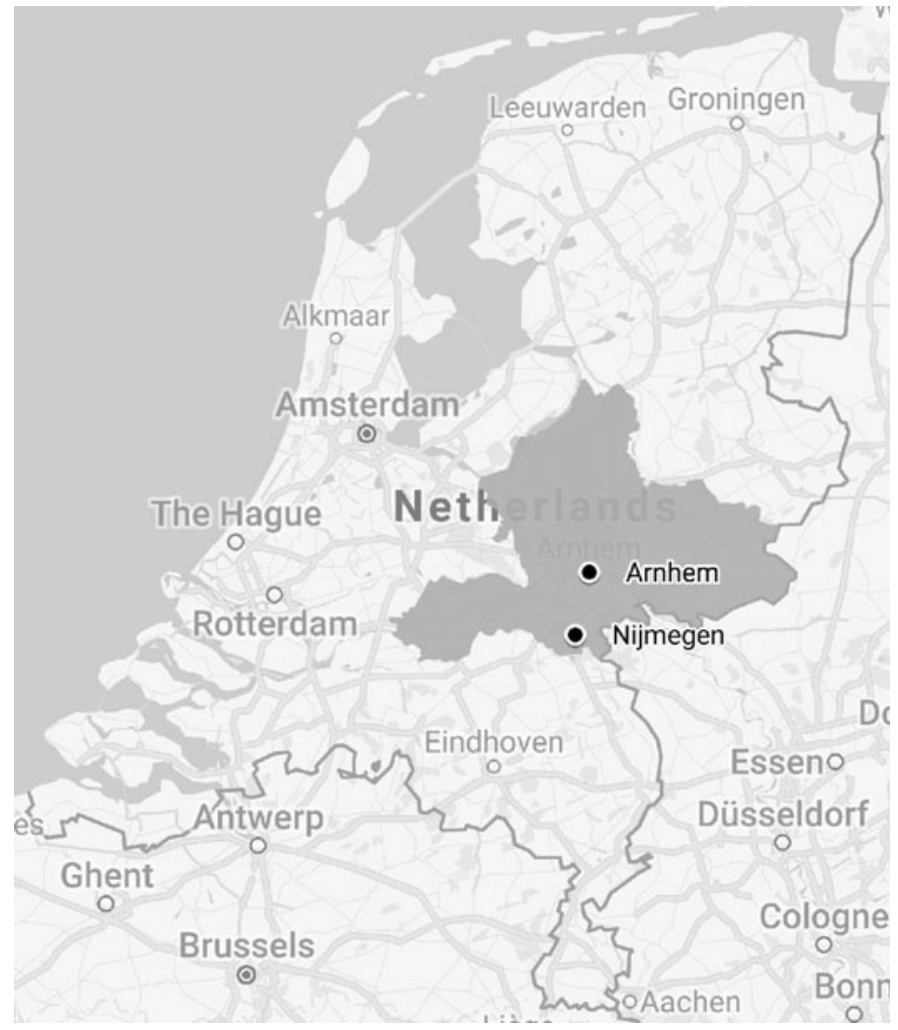

Figure 1: Map of Arnhem and Nijmegen within the province of Guelders

Their current demographic makeup is very similar: their populations' age distribution, average personal income, country of origin, as well as property prices, unemployment levels and crime figures are all comparable. ${ }^{17}$ Both cities saw rapid urbanization after their relatively late industrialization at the turn of the twentieth century. ${ }^{18}$ While Nijmegen has hosted a university since 1923, making it a comparatively well-educated city, Arnhem's inhabitants are currently relatively highly educated as well. Today, moreover, many people commute between Arnhem and Nijmegen, making it even harder to pinpoint major differences between the populations of the two cities.

17 http:/ /arnhem.buurtmonitor.nl/jive?cat_show_code=c635766100395394863 accessed 24 Nov. 2017). The average income in both cities was roughly equal in 1952 as well. CEBUCO, Vademecum, 12.

18 E. de Boer, 'De kans op een beter bestaan: de groei van de bevolking van Arnhem sinds 1815', Bijdragen en Mededelingen Gelre, 74 (1983), 132-55, at 132, 137. 
In describing the relationship between Arnhem and Nijmegen, observers often make a distinction between the two by referring to (what they perceive as) the cities' distinct identities. The way in which a city's image is shaped by various actors determines how a place 'achieve[s] coherence and how that coherence reproduces itself' ${ }^{19}$ This coherence makes the city into a 'culturally constructed space', existing of a 'collection of symbols and images'. ${ }^{20}$ While a city's image may be based on physical qualities, such as architecture and urban planning, it may also be determined by cultural qualities, such as a city's 'character'. As I will demonstrate, the two types are often related. There are different agents, different discourses and different agendas that influence these socially constructed images.

A comprehensive study on historical city image exists for neither Arnhem nor Nijmegen. The following is an attempt to provide such an analysis. In addition to secondary literature on the cities of Arnhem and Nijmegen in the pre-modern and modern era, Dutch newspapers (18802016) were searched for specific keywords ('typically Nijmegian', 'Arnhem custom', ' ... character',' ... nature', ' ... habit', ' ... trait', ' ... practice', ' ... attribute'). Travelogues and ethnographic books with 'Arnhem' or 'Nijmegen' in their title were also part of the sample.

\section{The historical image of Nijmegen}

Since the end of the nineteenth century, Nijmegen's tourist office has tried to present the city as both green and ancient. ${ }^{21}$ At that time, many people sought to escape from industrialization, and started looking for green oases to live in..$^{22}$ Nijmegen's politicians kept manufacturers at bay and the city came to be known as a true 'pensionopolis'. ${ }^{23}$ After the First World War, factory jobs finally came to Nijmegen, causing the city partly to lose its affluent image. ${ }^{24}$ Subsequently, the balance tipped more and more toward presenting Nijmegen as the 'oldest city of the Netherlands'. As of 2016, the city's history has been 'museumized', leading one scholar to remark that no other Dutch city asserts its historical image as much as Nijmegen. ${ }^{25}$

${ }^{19}$ H. Molotch, W. Freudenburg and K. Paulsen, 'History repeats itself, but how? City character, urban tradition, and the accomplishment of place', American Sociological Review, 65 (2000), 791-823, at 792.

${ }^{20}$ E. del Lago, 'The city as social display: landed elites and urban images in Charleston and Palermo', Journal of Historical Sociology, 14 (2001), 374-96, at 376.

${ }^{21}$ M. Icks, 'Komt dat zien: geschiedenis in Nijmegen: de toeristisch-historische beeldvorming van Nijmegen vóór en na de oorlog', Ex Tempore, 21 (2002), 152-64, at 160.

22 P. Kooij, 'Het imago van Nederlandse steden tot het begin van de twintigste eeuw', Groniek, 162 (2004), 43-58, at 51.

${ }^{23}$ A. van de Sande, 'Met verjongden luister', in H. Bots and J. Brabers (eds.), Nijmegen: Geschiedenis van de Oudste Stad van Nederland (Wormer, 2005), 135-84, at 180; P. Klep, 'De economische en sociale geschiedenis van de twintigste eeuw', in ibid., 263-375, at 264.

${ }^{24}$ Klep, 'De economische', 331.

${ }^{25}$ L. Savenije, 'Nijmegen: stad met een grensoverschrijdend verleden', Jaarboek Numaga, 58 (2011), 127-33, at 127. 
According to some, the rediscovery of the city's purported BatavianRoman roots has helped strengthen urban self-confidence among average Nijmegians. ${ }^{26}$

Professional historians have (implicitly) affirmed city officials' branding of Nijmegen as a 2,000-year old settlement, despite a profound lack of 'cultural continuity' in the region. ${ }^{27}$ The consequence is that the city itself is ascribed a particular mentality by observers, derived from its long history of fighting against foreign powers: 'autonomous, wayward, and selfassured'. ${ }^{28}$ Its pride, conveyed through symbols, myths and architecture, is seen as stemming from attempts by Nijmegen's rulers to construct a sovereign city-state. The city's history is repeatedly cited as an influence on its present-day character. ${ }^{29}$

Both in the past and today, Nijmegen was often labelled both a Roman Catholic city and a progressive city. Historically, Catholicism was the religious denomination of the majority of the city's inhabitants, and the instalment of a Catholic university in 1923 increased its visibility. ${ }^{30}$ While secularization set in during the 1960s, to some Nijmegen was still a 'Catholic city' in the $1980 \mathrm{~s},{ }^{31}$ or even the 2000s. ${ }^{32}$ Nijmegen's political image, however, is determined by its alleged progressivism. Student activism and the instalment of a progressive city council in 2002 yielded the nickname 'Havana on the Waal [river]'. ${ }^{33}$ According to the authoritative history of Nijmegen, there is no city in the Netherlands with a greater cultural heritage from the 1970s. ${ }^{34}$ Occasionally, these two disparate parts of Nijmegen's image are brought together: in 1997, LGBT rights group Villa Lila argued that 'promoting progressive developments on the axis of religion and homosexuality' was a 'typical Nijmegian tradition'. ${ }^{35}$

Perhaps the most prominent aspect of Nijmegen's image is 'folksiness': to many, the city is convivial and inhabitants enjoy the good things

${ }^{26}$ D. Verhoeven, 'Het imago van Nijmegen', Jaarboek Numaga, 58 (2011), 12-18, at 14-15; J. Geurts, 'Nijmegen in de zestiende eeuw: een stad en haar mythen', Jaarboek Numaga, 58 (2011), 38-57, at 45, 47.

27 W. Frijhoff, 'Hoe cultuurhistorisch is de geschiedenis van Nijmegen', Jaarboek Numaga, 56 (2009), 162-8, at 165 .

28 Geurts, 'Nijmegen in de zestiende eeuw', 39.

29 Ibid., 40; De Gelderlander, 27 Feb. 2010.

30 E.g. in 1850, there were 15,000 Roman Catholics compared to 6,000 Protestants. J. Brabers, 'Het katholieke imago van Nijmegen, 1850-1965', Jaarboek Numaga, 58 (2011), 74-95, at 7782.

${ }^{31}$ De Gelderlander, 16 Feb. 2008. Interview with Mayor Thom de Graaf.

32 Het Parool, 18 Jan. 2003.

${ }^{33}$ In 2016, students made up $12 \%$ of Nijmegen's population. For Amsterdam this was less than 6\%. http://swm.nijmegen.nl/p8310/bevolkingsontwikkeling; www. studiekeuze123.nl/steden/amsterdam (last accessed 24 Nov. 2017). 'Havana aan de Waal': De Volkskrant, 22 July 2002.

34 R. Wolf, 'Gemoedelijk, links en academisch: Nijmegen 1985- ', in Bots and Brabers (eds.), Nijmegen, 467-85, at 485 .

35 De Gelderlander, 22 Apr. 1997. 
in life. ${ }^{36}$ Nijmegen, so it is said, has 'a particular atmosphere of geniality' ${ }^{37}$ In 2009, its mayor called the city 'cosy and informal' ${ }^{38}$ It is often described, moreover, as the 'most Southern city of the Northern Netherlands', referring to the stereotypical image of the Southern, majority Catholic Netherlands as festive, jovial and care-free. ${ }^{39}$ A small survey among Nijmegians (1986) found that 64 per cent saw their city as 'cosy and lively'.$^{40}$ Such recent, clichéd characterizations of the city and its inhabitants hardly ever come with a demographic, historical or localized specification. The implication is that all of Nijmegen is - and has always been - folksy, cosy and 'Burgundian'.

\section{The historical image of Arnhem}

In many ways, the image of Arnhem is fundamentally different from that of Nijmegen. However, to observers, the city's history is equally important for explaining its present-day character. Before growing in size in the eighteenth century, Arnhem was a relatively modest town that missed out on the Dutch Golden Age. It acquired 'the allure of a local capital' around $1700{ }^{41}$ and has been the official capital of the province of Guelders since 1817. The nineteenth century was a period of growth and modernization for Arnhem. ${ }^{42}$ During these years, officials actively built a city image of which many parts are still intact today. ${ }^{43}$

The physical surroundings of Arnhem have historically played a significant role in its image. In the nineteenth century, Arnhem was somewhat romantically - known as a 'beautifully situated, green city' and an 'anti-industrial' city. ${ }^{44}$ This 'green' image dates from at least the seventeenth century. ${ }^{45}$ According to some, the council 'preferred white collars over black hands' ${ }^{46}$ While this is a simplification, if not a falsehood, ${ }^{47}$ Arnhem's green image has stuck. A small survey among Arnhemmers (i.e. the city's inhabitants) from the beginning of the twentyfirst century found that they saw their city as 'cherishing its tranquillity

${ }^{36}$ Savenije, 'Nijmegen: stad', 129. Recent examples are Het Parool, 18 Jan. 2003; De Gelderlander, 7 June 2010.

37 Brabers, 'Het katholieke imago', 94.

${ }^{38}$ De Gelderlander, 22 July 2009.

${ }^{39}$ De Gelderlander, $27 \mathrm{Feb}$. 2010. A quote from the previously cited local politician. See also O. Atzema, A. Dietvorst and R. Spee, Buitenste Binnenbeeld: Beeldvorming en Dagrecreatief Gedrag in het Rijk van Nijmegen (Nijmegen, 1986), 38.

40 P. Biemans and J. van der Putten, Rondom Nijmegen 1986: Een Leeronderzoek van SociologieStudenten rond het Beeld dat Inwoners van hun Stad Hebben (Nijmegen, 1986), 24.

${ }^{41}$ M. Boone, D. Verhoeven and W. Frijhoff, 'Drie critici over de geschiedenis van Arnhem', Arnhems Historisch Tijdschrift, 30 (2010), 24-44, at 26, 28.

42 P. van Wissing, 'Epiloog: verbeelding van een stad', in I. Jacobs and F. Keverling Buisman (eds.), Arnhem: Van 1700 tot 1900 (Utrecht, 2009), 322-51, at 323, 346.

43 Ibid., 325; T. van Zijpenstein, Over de Stad Arnhem (Oosterbeek, 1981), 8.

44 B. Kerkhoffs, Knipoog naar Arnhem van Toen (Arnhem, 1983), 62, 72.

45 Wissing, 'Epiloog', 324.

${ }^{46}$ De Gelderlander, 22 June 1985, 'The backs to one another', 5.

47 De Boer, 'De kans', 145 . De Boer makes an explicit comparison to Nijmegen. 
and its greenness' ${ }^{48}$ Another modest poll reported that they thought of their city as a 'park city', not an 'industrial city'. ${ }^{49}$

A second, more ubiquitous characterization of Arnhem's history is that of a well-off, luxurious city. Writing about nineteenth-century life in Arnhem, one historian stated that 'a luxurious lifestyle ... typified the city. Arnhem had allure. ${ }^{50}$ This image has proven persistent. Similarly, an impressionistic ethnography of the province of Guelders (1970) characterized Arnhem as a city of 'genteel administrators': a 'well-situated bourgeoisie' that is 'too well-fed and too well-dressed'. The author accused (historical) Arnhemmers of pompousness, a 'certain mimicking of aristocratic manners' ${ }^{51}$ Another more recent portrait of both Arnhem and Nijmegen (2008) calls the former 'a city that attempts to be dignified, efficient and understated', but always comes up a little short. To the author - who is from Nijmegen - Arnhem is 'a somewhat formal, civil middleclass city'. ${ }^{52}$ The reputation of Arnhem as a rather reserved city has a long history: in 1906, De Gelderlander also referred to the 'world-famous stiffness' of Arnhem's social life..$^{53}$ A component of these characterizations is Arnhem's image as a historically conservative city. ${ }^{54}$ The city was known as a 'white collar city' until long after the Second World War. ${ }^{55}$

'Arrogant' is another popular characterization of Arnhemmers. In 2013, Arnhem-born Vitesse footballer Davy Pröpper explained his lack of popularity among supporters: ' $I$ 'm not the prototype of an Arnhemmer ... Whiny, tough, arrogant, big-mouthed - doesn't describe me. ${ }^{56}$ To some, Arnhemmers' arrogance is a historical fact: 'there is an air of smugness and complacency around them ... formed and strengthened through the centuries' ${ }^{57}$ Curiously, most Arnhemmers seem to have a similarly negative opinion. A small-scale survey from 2004 found that the top five traits Arnhemmers assigned to themselves were: (1) surly (2) standoffish (3) passive (4) stubborn (5) sporty. ${ }^{58}$ Recently, one journalist proclaimed: 'if you've got a room filled with people who are enthusiastic about the city, chances are none of them are from Arnhem'. ${ }^{59}$ The question is, though, which 'Arnhem' observers are describing when alluding to arrogance, stiffness, green pastures and liberalism. There is an apparent class bias to

48 Dormans, van Houtum and Lagendijk, De Verbeelding, 31.

${ }^{49}$ M. van Meurs, 'Inleiding', in H. van Bemmel and M. van Meurs (eds.), Arnhem in de Twintigste Eeuw (Utrecht, 2004), 12.

${ }^{50}$ Wissing, 'Epiloog', 323.

51 J. Gazenbeek and J. de Groot, Leer Mij Ze Kennen ... De Geldersen (Leiden, 1970), 77, 9-10.

52 Stichting Achterland, Arnhem-Nijmegen: Poëtische Verkenning van een Regio (Zeist, 2008), 13.

53 De Gelderlander, 20 Jan. 1906.

54 Van Meurs, 'Inleiding', 11-12.

55 W. de Jong, Kijk Op en Om Arnhem (Zwolle, 1982), 94.

56 De Gelderlander, 28 Mar. 2013.

57 Gazenbeek and De Groot, Leer Mij, 9.

${ }^{58}$ Van Meurs, 'Inleiding', 12.

59 De Gelderlander, 9 Feb. 2013. 
this dominant image. It should be no surprise that many Arnhemmers and outsiders declare the city to be historically very divided. ${ }^{60}$

\section{Relations between the two cities}

The closeness of Arnhem and Nijmegen means that they have an extensive history together. Often, specific parts of this history are highlighted to present a coherent idea of the two cities and their (supposedly inherent, long-standing) differences. Contemporary scholars and journalists contend that the animosity between Arnhem and Nijmegen has a 'long tradition', ${ }^{61}$ making them 'sworn enemies since olden days' ${ }^{\prime 2}$ who are currently each other's 'polar opposites' ${ }^{63}$ Historians often present the French Revolution and its consequences as an important turning point. Ancien régime Nijmegen had been one of Guelders' principal cities, but, by the end of the eighteenth century, 'jealous sister cities' like Arnhem were looking to rid it of its pretenses. ${ }^{64}$ The French Revolution cemented Arnhem's status as capital of the province of Guelders. It became the fastest growing town of the Netherlands in the nineteenth century. The popular interpretation is that the older, illustrious Nijmegen was forced to concede. ${ }^{65}$ Apparently, now Arnhem had come to stand for prosperity, Nijmegen for poverty. ${ }^{66}$

In comparing the two cities, observers essentialize certain differences. For many of the cities' inhabitants, the neighbouring 'other' helped and helps - cultivate their own city image. Thus, Arnhem is seen to have developed a 'Protestant-conservative climate' while Nijmegen was a 'nearly completely Catholic city'. ${ }^{67}$ In opposition to Nijmegen as the 'most Southern city of the Northern Netherlands', Arnhem was often called the 'most Northern city of the Southern Netherlands'. ${ }^{68}$ A recent survey among Arnhem policy-makers found that they thought Nijmegen was a city of 'Southern conviviality', especially in contrast to their own 'strict and elitist' city. ${ }^{69}$ One politician, having worked in both cities, remarked in 1985: 'Nijmegians are more casual, easier. The mentality is so different!'70 That same newspaper special on the relationship between the two cities (titled 'Back to back') surveyed people from the Western Netherlands

${ }^{60}$ Dormans, van Houtum and Lagendijk, De Verbeelding, 40-1, 103-8. Previously cited authors (Gazenbeek, De Jong, Wissing, Kerkhoffs) all agree.

61 D. Verhoeven, Het Gelderse Gevoel en de Betekenis van Grenzen in Ruimte en Tijd (Nijmegen, 2015), 15.

62 Stichting Achterland, Arnhem-Nijmegen, 12.

63 G. Janssen, 'Middelen van bestaan', in van Bemmel and van Meurs (eds.), Arnhem, 137.

64 Van de Sande, 'Met verjongden luister', 170.

65 De Gelderlander, 22 June 1985, 4.

66 Ibid., 17.

67 Ibid., 4.

68 Dormans, van Houtum and Lagendijk, De Verbeelding, 41; Savenije, 'Nijmegen: stad', 129.

69 Dormans, van Houtum and Lagendijk, De Verbeelding, 41.

70 De Gelderlander, 22 June 1985, 2. 
on their view of Arnhem and Nijmegen. According to 66 per cent of them, people in Nijmegen knew how to have fun - which was said of Arnhemmers by just 18 per cent. ${ }^{71}$ Nijmegen is often compared to Arnhem in this way, and comes out 'more colourful, folksier and more wayward' ${ }^{72}$

Not everyone agrees with this clichéd opposition between Arnhem and Nijmegen. A small survey from 2000 found that the 'time-honoured rivalry' between the two had dwindled. ${ }^{73}$ And in 2013, in a series of newspaper articles intended to welcome the new mayor of Arnhem, a supporter of Vitesse told a journalist that she had hated living in Nijmegen: 'Surly crowd, those Nijmegians! Awful.' To her, Arnhem was the real cosy city of the region. ${ }^{74}$ Another local told the same newspaper that he actually enjoyed visiting Nijmegen, though he joked that 'the best thing about Nijmegen is the last train to Arnhem' ${ }^{75}$ Such comments remind us that the experience of city life is multifarious, and that images are selective. To some, the rivalry between the two cities is playful or even non-existent.

Many observe one major common character trait between the two cities, namely: 'nuilen', meaning a critical disposition - or 'whining'. This habit is described as both typically Nijmegian ${ }^{76}$ as well as 'Arnhems' (i.e. typical of Arnhem) in contemporary newspaper articles. ${ }^{77}$ One Arnhemmer explained the city's paradoxical mentality, connecting a fondness for Arnhem with one for Vitesse: 'We scold the Vitesse team when things go bad, but we're proud as a dog with seven dicks when they do well. ${ }^{17}$

Not only are the city images discussed above clear generalizations, they are often created with a certain goal in mind. Place branding is part of these efforts, a tool that has grown more purposeful over the course of the twentieth century. It has always been an instrument for helping cities compete in the 'arena of interplace competition'. Because of the expanding mobility of money and people, these intensifying urban rivalries are no longer frivolous. In fact, they are about competing over limited financial, human and cultural resources and partly determine a city's future. ${ }^{79}$ Historically, local politicians have played a role as well, comparing their city (favourably) to neighbouring competitors. ${ }^{80}$ Others, however, including politicians themselves, have recently pointed toward the role of the media, who are 'out to create oppositions that aren't

71 Ibid., 10. The title 'Back to back' refers to the cities' closeness and their supposed mutual animosity.

72 Stichting Achterland, Arnhem-Nijmegen, 14.

73 Dormans, van Houtum and Lagendijk, De Verbeelding, 89.

74 De Gelderlander, 11 Apr. 2013. Interview with Karin Dielen.

75 De Gelderlander, 28 Feb. 2013. Interview with Gerrit Dassen.

76 De Gelderlander, 18 Jan. 2003, 7 July 2003, 20 May 2005, 10 Oct. 2007, 21 Mar. 2009.

77 De Gelderlander, 19 May 2012, 21 Mar. 2015.

78 De Gelderlander, 28 Feb. 2013.

79 G. J. Ashworth, M. Kavaratzis and G. Warnaby, 'The need to rethink place branding', in eidem (eds.), Rethinking Place Branding: Comprehensive Brand Development for Cities and Regions (Cham, 2015), 1-11, at 4.

80 Kooij, 'Het imago', 43. 
even there'. ${ }^{81}$ It should be noted that a myopic view can lead to the conclusion that individual cities, such as Arnhem and Nijmegen, are wholly unique in many ways. Yet well-known Dutch historian Johan Huizinga's characterization of the Dutch in general, for instance, overlaps with many popular ideas about Nijmegians and Arnhemmers. ${ }^{82}$

\section{Localism}

While the promotion of city images is not a new phenomenon, certain trends are visible. In the Netherlands, interest in, and the promotion of, local culture - localism - has seen a significant rise since at least the 1980s. ${ }^{83}$ Social geographer Ben de Pater asserts that in the past two centuries the country has changed from a 'mosaic of closed-off regional societies' to one where such societies were 'taken up by larger inter-regional frameworks'. As part of deliberate nineteenth-century nation building, school curricula converged and national holidays were created. A continuing transport revolution and the rise of new media meant increasing inter-regional contact. As a consequence, local cultural identities weakened - a development that was furthered in the 1970s by processes associated with the term 'globalization'. However, De Pater signals a counter reaction with its starting point in the 1980s, in which associations have fought to protect their local cultures against what they saw as 'Hollandization'. A renewed 'local awareness' was born, encouraged by local and regional media, which were able to 'stimulate the social cohesion from which they themselves profit' ${ }^{.}{ }^{84}$

The process of 'othering' has proved important for the celebration of local cultures, as seen in the oppositional images of Arnhem and Nijmegen. In an essay on what he called the 'folklore of small differences', Dutch philosopher Cornelis Verhoeven observed that for places, the rivalry with a neighbour is what produced local identities. ${ }^{85}$ These constructed differences, this process of 'bordering ${ }^{\prime},{ }^{86}$ means that small differences are taken to be significant, and are magnified 'with the use of symbols and media' ${ }^{87}$ As said in the introduction, many scholars contend that such processes of inclusion and exclusion are the most apparent in sports. To

81 De Gelderlander, 22 June 1985, 13.

82 A. van der Zeijden, "'Of ik ben niemand, of ik ben een hele natie": de Nederlandse culturele identiteit', Volkscultuur, 9 (1992), 5-27, at 8-9.

83 B. van Straalen, 'Erfgoed buiten en binnen: cultuurhistorie en musea', in D. Verhoeven et al. (eds.), Gelderland 1900-2000 (Zwolle, 2006), 514.

84 B. de Pater, 'De regionale metamorfose van Nederland vanaf het midden van de vorige eeuw', Volkskundig Bulletin, 17 (1991), 15-40, at 15, 21-5, 34; J. Hemels, 'De krant van Gelderland: journalistiek in de regio tussen cultuur en commercie', in Verhoeven et al. (eds.), Gelderland 1900-2000, 504-8, at 508.

85 C. Verhoeven, 'Folklore van het kleine verschil', NRC Handelsblad, 18 Oct. 1993.

${ }^{86} \mathrm{H}$. van Houtum and T. van Naerssen, 'Bordering, ordering and othering', Tijdschrift voor Economische en Sociale Geografie, 93 (2002), 125-36.

87 Verhoeven, 'Folklore van het kleine verschil'. 
borrow a phrase from John Hoberman, sportspersons, sports clubs and supporters become 'proxy warriors' for their respective local cultures. ${ }^{88} \mathrm{I}$ will now turn to these proxy warriors.

\section{The history of NEC and Vitesse}

The rise of organized football in the Netherlands was similar to that of other western European countries, though professionalization came comparatively late. The first football clubs were founded at the end of the nineteenth century, mostly by men from the (higher) middle class. In the inter-war period, those with more modest incomes followed. NEC and Vitesse were exemplary of this general trend. Vitesse was founded in 1892 by highly educated young men. Among its players was the occasional doctor, and even one baron. NEC's precursor, Eendracht, was founded in 1900, by a group of boys from the relatively impoverished lower city of Nijmegen. In 1910, this club merged with NVV Nijmegen, and became known as NEC.

Before the nationalization and professionalization of Dutch football in 1954 most matches had a fairly local or regional character. NEC and Vitesse played in the so-called Eastern district, where clubs from two provinces competed against each other: Guelders and Overijssel (to the north-east of Guelders). Only the champions of the Eastern district played at a national level to determine the winner of the national championship.

When NEC and Vitesse played their first match in 1916, the cultural difference between the two teams must have been felt both on and around the field. According to one reporter, NEC had chased the ball 'like devils' ${ }^{89}$ In the inter-war period, teams that were seen as 'proletarian' were often accused of foul play. Their style was seen as very different from that of 'gentlemen's teams' such as Vitesse. Explicit references to class differences were often taboo for sports journalists, but they did frown upon harsh (or even 'too enthusiastic') play. References to this rougher style were code for a club's 'modest' origins and were used to delegitimize its results. ${ }^{90}$ In reality, harsh play was not exclusive to 'proletarian' clubs. ${ }^{91}$ Regardless, in 1923, a plan was devised to start an exclusive elite competition - which included Vitesse. However, it was quickly abandoned. There was already an explicit class divide in Dutch society, and some felt that it should not be brought into the world of sports. ${ }^{92}$ In the 1930s, increasingly successful

88 J. Hoberman, Sport and Political Ideology (London, 1984), 6.

89 De Gelderlander, 11 Apr. 1916.

90 Similar class-based discrimination took place in Germany. U. Merkel, 'Milestones in the development of football fandom in Germany: global impacts on local contests', Soccer $\mathcal{E}$ Society, 8 (2007), 221-39, at 225.

91 A 1932 commemorative book makes several mentions of rough play on Vitesse's part. Anon., Gedenkboek Uitgegeven ter Gelegenheid van het 40-Jarig Bestaan der Arnhemsche Voetbal$\mathcal{E}$ Athletiekclub 'Vitesse' 1892-1932 (Arnhem, 1932), 14, 15, 36.

92 De Gelderlander, 17 Jan. 1923. 
'proletarian' clubs such as NEC supposedly changed their playing style somewhat, ${ }^{93}$ while 'gentlemen's clubs' like Vitesse started losing more often. One newspaper saw the latter's relegation in 1935 as a sign of the times: 'In the world of sports we now see the decline of the third estate and the rise of the fourth. Here, the working man overtakes the middle-class ["burger"] sportsman. ${ }^{\prime 94}$

In the years before and after the Second World War, clubs became progressively more mixed in terms of class, yet the perceived sharp contrast between NEC and Vitesse was upheld by supporters and journalists. As was stated in NEC's commemorative book, published in 1950, which conceived of the club's pre-war rise as one long struggle against an arrogant enemy: 'Leading members of the ruling classes, at the beginning of this century, looked down upon those simple men [and] their silly plan. ${ }^{95}$ Half a century later, not much had changed in the anniversary books of Jaap van Essen (2000) and Michel Gunsing et al. (2001), commemorating a hundred years of NEC history. NEC was still considered a real 'proletarian' club. Ex-manager Leen Looyen was interviewed, who proclaimed that there was an observable difference between NEC and 'frigid institutions' such as Vitesse. ${ }^{96}$ In a small survey from 2001, carried out for a report on NEC's image, supporters and non-supporters from Nijmegen also maintained that NEC was in fact a 'proletarian' club. ${ }^{97}$

Reckoning with Vitesse's elitist history has proven more difficult. Early commemorative books only implicitly referenced the prevailing mindset with phrases such as 'noblesse oblige' and 'Good old Vitesse'. ${ }^{98}$ In a book written for the club's one-hundred-year anniversary (1992), the club's ballot committee, which was meant to secure its culture via exclusivity, featured as a funny factoid from a distant past. ${ }^{99}$ A more recent book (2011) included an interview in which a supporter argued that even though the board of Vitesse may have been elitist, 'its supporters had been regular people'. ${ }^{100}$ So while the club was occasionally called a 'sophisticated white collar club', $^{101}$ its self-image was adjusted somewhat over time. However, a perceived opposition in social class is a good foundation for

93 De Gelderlander, 28 Feb. 1936, 11 Nov. 1935. By 1947, Vitesse had become the roughest of the two. De Gelderlander, 6 Oct. 1947.

${ }^{94}$ De Gelderlander, 29 Apr. 1935. In Dutch, 'burger' implies someone is a respectable citizen, often from the middle class.

95 G. Wijers, J. Meuleman and L. Broekkamp, De Geschiedenis van N.E.C. bij haar Gouden Jubileum 1900-1950 (Nijmegen, 1950), 4.

96 J. van Essen, 100: De Historie van NEC Nijmegen (Nijmegen, 2000), 197; M. Gunsing et al., Hillemuil NECs: Ups en Downs van NEC 1954-2000 (Nijmegen, 2001), 2, 12, 16.

$9789 \%$ of season ticket holders; $72 \%$ of non-supporters. H. van Houtum, De Verbondenheid met NEC: Onderzoeksrapport (Nijmegen, 2001), 46.

98 Anon., Gedenkboek, resp. 28, 105.

99 J. Brons, A.V.C. Vitesse 1892-1992 (Arnhem, 1992), 5.

100 P. Bierhaus and F. Reurink, Vites! 9 Verhalen over Onvoorwaardelijke Liefde voor Vitesse (Arnhem, 2011), 43.

101 Statement from then-technical director Ted van Leeuwen. NRC Handelsblad, 17 Oct. 2011. 


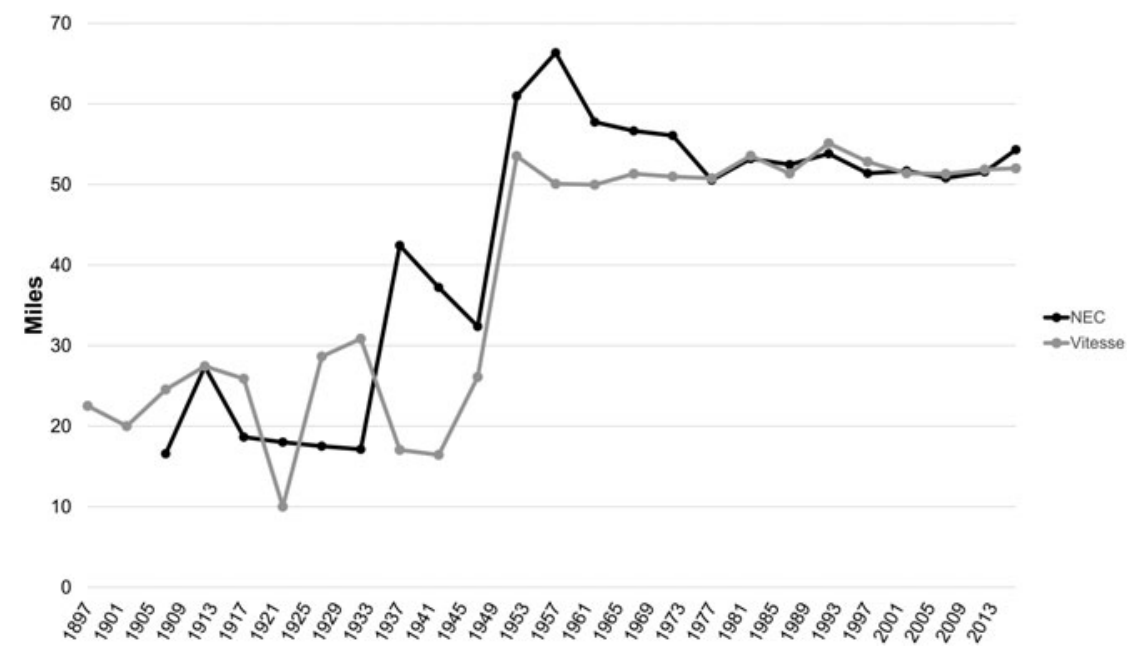

Figure 2: Average distance to competitors (as the crow flies) for NEC and Vitesse

club rivalries, meaning class differences between NEC and Vitesse are still maintained by many. ${ }^{102}$

\section{Nationalization and the appropriation of city images}

The nationalization and professionalization of Dutch football in 1954 has been of great consequence to processes of club identification. In the 1934/35 season, NEC's opponents were based - on average - just 19 miles away. Only 20 years later, the distance was 56 miles (as the crow flies; see Figure 2) and the Eastern district in which NEC and Vitesse had played ceased to exist.

At the highest levels, intra-city rivalries became scarce. In 1922/23, Vitesse had played three other teams from Arnhem, but after 1954, it would never play a competitive match against another team from Arnhem again. NEC's board opted for the club's professionalization because Quick Nijmegen, the city's most well-known team, declined. NEC's wish for Nijmegen's representation at the highest level therefore meant that the city lost its intra-city confrontation as well. ${ }^{103}$ As in other European countries, nationalization meant that most professional clubs soon became the sole representative of their city, region or even province. ${ }^{104}$

102 Dmowski, 'Geographical typology', 339.

103 M. Derks, 'Het kanon uit Curaçao: NEC's geromantiseerde postkoloniale voetbalerfenis', Jaarboek Numaga, 63 (2016), 144-62, at 150.

104 E.g. in Germany in the 1970s. Merkel, 'Milestones', 228. 
The consequence was that from the 1950s onwards, Vitesse and NEC increasingly started presenting themselves as typically Arnhems and Nijmegian. Club officials and supporters appropriated aspects of the city image and city culture. The clubs had been quick to use their uniforms to reference their respective cities. The earliest kits of both clubs were in Nijmegian red and black, 'with a hint of green symbolizing the grass', 105 and Arnhem blue and white. Club songs were another vehicle to claim actively the representation of one's city. The NEC march of 1934 contained no references to Nijmegen, but the current club song, written in 1966, opens with: 'There, on the banks of the Waal, lies the old imperial city', and assigns players the task of upholding the colours of '[stadium] Goffert, club and city'. ${ }^{106}$ Before the war, Vitesse supporters sang: 'Thou, club of Guelders' premier city ... Again and again your glory caresses the heart of Arnhem. ${ }^{107}$ Currently, fans sing: 'Here in the city on the Rhine, you can't escape being a Vitesse supporter.'

Emblems, an important part of a club's branding, were changed to reflect city representation. Early emblems featured little more than the club name, its colours and the founding year. Since the 1960s, NEC's emblem has incorporated the image of Nijmegen's coat of arms, and the current emblem (since 2000) also prominently features its two-headed eagle. Vitesse's emblem was changed in 1984 and now markedly resembles Arnhem's coat of arms (see Figure 3). ${ }^{108}$ More recently, mascots were authorized by both clubs. Since 2011, NEC's costumed character 'Bikkel', a legionnaire, forms a way to appropriate Nijmegen's Roman history. Earlier, in 2008, Vitesse adopted a live eagle, alluding to both Arnhem's crest as well as its name, found in sources since 893 (Arnhem is derived from 'Arend-heim', or 'Home of the eagle'). These are not random policies. Especially since the 1990s, many football clubs in the Netherlands have actively managed club identification, as have NEC and Vitesse. They now see themselves as businesses in the 'experience economy'. ${ }^{109}$

Clubs are discursively made into representatives of their city and their city's culture - by insiders and outsiders. Journalists have described Vitesse-NEC matches as 'Arnhem versus Nijmegen' since the 1930s. ${ }^{110}$ Now, historians present NEC as the vehicle of the Nijmegian sense of community, ${ }^{111}$ while the Dutch public thinks of 'Vitesse' when they hear the word 'Arnhem'. ${ }^{112}$ Consequently, when discussing the two cities or

105 Van Essen, 100: De Historie, 166.

106 Ibid., 156-7.

107 Anon., Gedenkboek, 34.

108 The two-headed eagle of Nijmegen references its imperial history; that of Arnhem refers to its Hanseatic past.

109 R. Heeg, 'Avondje Arnhem', Adformatie, 38 (2010), 26-9; Anon., 'Werken aan een voetbalmerk: NEC en de marketingadviesraad', Tijdschrift voor Marketing, 36 (2002), 40-1.

110 De Gelderlander, 8 May 1936.

111 Klep, 'De economische', 329.

112 L. Egberts, 'Chosen legacies: heritage in the construction of regional identity', UvA dissertation, 2015, 243. 

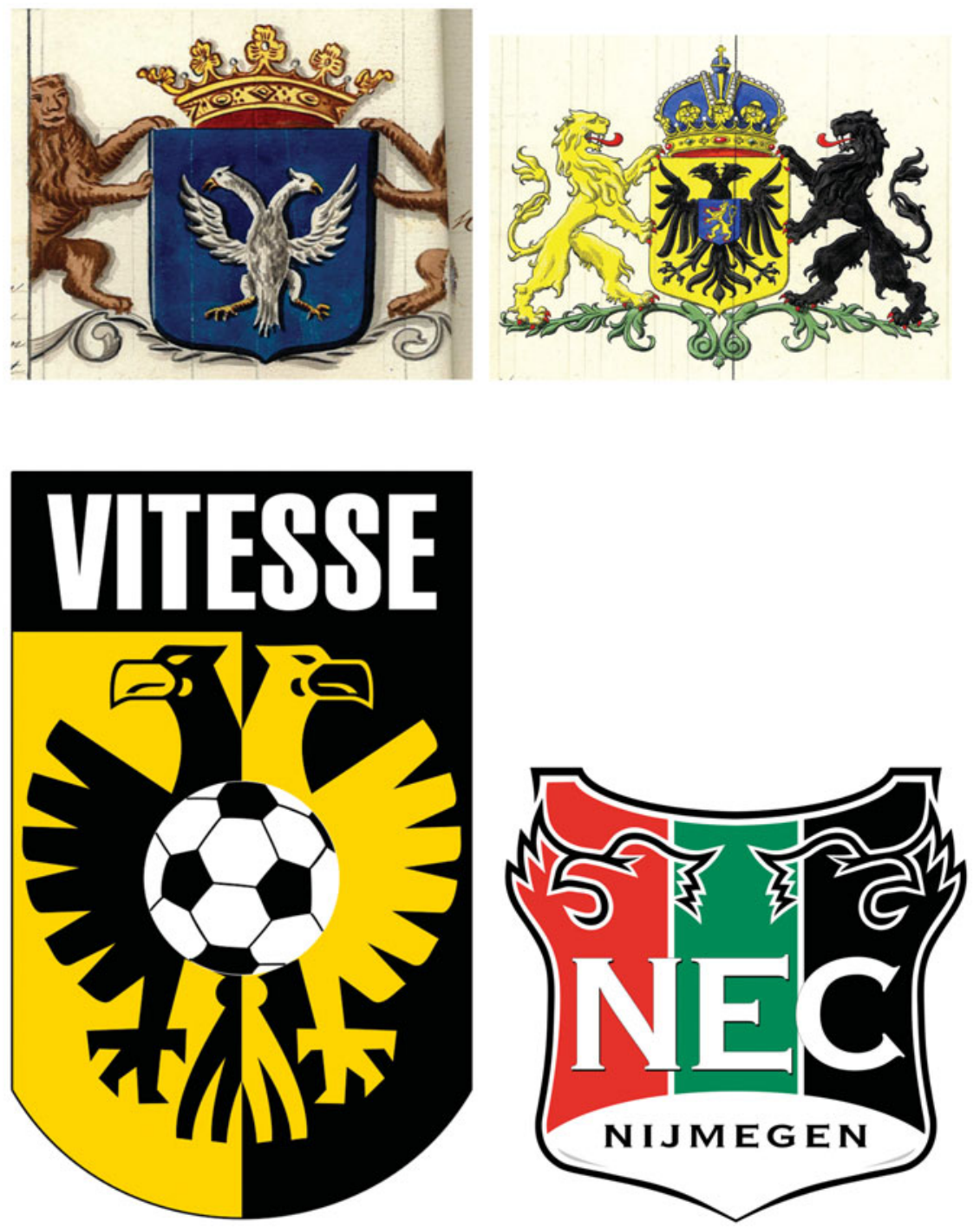

Figure 3: (Colour online) Top: the crests of Arnhem (left) and Nijmegen (right); bottom: the emblems of Vitesse (left) and NEC (right) (crests: Hoge Raad van Adel, The Hague, Archive of the Hoge Raad van Adel, inv.nr. 612, fol. 74 en fol. 1; emblems: wikimedia.commons.org)

their rivalry, many twenty-first-century books and articles mention the clubs as well. ${ }^{113}$

113 E.g. Stichting Achterland, Arnhem-Nijmegen, 4; W. Sanders and L. Boelens, De Grote KANAtlas: Mentale Atlas van het Stedelijk Netwerk Arnhem-Nijmegen (Rotterdam, 2003); Trouw, 6 Nov. 2004. 
The purported mentality of the inhabitants of Arnhem and Nijmegen is projected onto the clubs. For his book on derby games (2008), journalist Menno Pot interviewed an NEC fan: 'Arnhem is the capital, you know, a little elitist. Arnhem has more financial possibilities. ${ }^{.114}$ Even the eagle of Vitesse was accused of 'typical Arnhem arrogance'. ${ }^{115}$ Like Nijmegen in relation to Arnhem, the less affluent NEC, with its 'anti-social' supporters, is made into the folksy underdog. ${ }^{116}$ In 2004, historian Jan Brabers declared that Nijmegians have an 'innate inferiority complex', and that 'while the factories in Nijmegen were running at full speed, the ladies and gentlemen of Arnhem sipped their tea before leaving for the city'. This, he claims, is directly visible in the relationship between NEC and Vitesse. ${ }^{117}$ The only purported shared trait of NEC and Vitesse supporters is their whining, or 'nuilen'. The cynicism of both crowds is often explained by their respective urban cultures. ${ }^{118}$ Any differences between city culture and club culture were and are neglected, leading to De Gelderlander's recent conclusion that 'Vitesse is synonymous with FC Arnhem'. ${ }^{119}$

Recently, the clubs have started acting as more than 'proxy warriors': they seem actively to aggravate existing animosity. A representative survey (2009) asked Arnhemmers and Nijmegians to describe each other. Apart from reiterating some of the stereotypes described above, the two groups proved quite fond of each other. In fact, 40 per cent of respondents claimed it was mostly the rivalry between NEC and Vitesse that fuelled hostility. Mayor Thom de Graaf concluded that Nijmegen and Arnhem were like oil and water, 'above all in football'. ${ }^{120}$ City identification and a complex mix of other identifications have strengthened the footballing rivalry, yet in recent years the enmity between the clubs is seen as worsening the relation between the cities. ${ }^{121}$

Thus far, most cited observers have presented the rivalry between Arnhem and Nijmegen, and Vitesse and NEC, as both natural and everlasting. However, it is in fact perpetual selective affirmations that in part create animosity. In the following, I will try to answer two questions that arise from the selective nature of the described processes: (a) Have Vitesse and NEC always been considered perfect representatives of their respective cities? (b) Do football clubs always derive their 'place'-based identity from their city?

${ }^{114}$ M. Pot, De Derby (Eindhoven, 2008), 157. 'Derby' games are popular confrontations between local sports teams.

115 De Gelderlander, 6 May 2009.

116 Pot, De Derby, 161; T. Jaski, 'De rivaliteit voorbij', Johan, 57 (2004), 46-50, at 49.

117 Jaski, 'De rivaliteit voorbij', 48.

118 E.g. for NEC: De Gelderlander, 25 July 2005; for Vitesse: De Gelderlander, 21 Mar. 2015.

119 De Gelderlander, 22 Feb. 2012.

120 De Gelderlander, 23 May 2009.

${ }^{121}$ Clubs from cities with a strong 'brand', such as Paris, have a harder time influencing city image. Ranc, 'Local politics', 62. 


\section{Fluctuations in representativeness and derby sentiment}

Before the Second World War, the most popular team of Nijmegen was Quick. It was considered Vitesse's 'sister club'; games between the two soon became legendary. ${ }^{122}$ Before the professionalization of Dutch football in 1954, Quick and Vitesse had played in the same league for 32 seasons. In contrast, NEC and Vitesse had only squared off in five seasons. Though games between the latter two also grew more popular in the 1930s and 1940s, ${ }^{123}$ NEC still had to reckon with its Nijmegian competitor. Quick had also adopted the red and black of Nijmegen in 1908, and supporters sang with pride of Quick as the city's oldest and most acclaimed representative. ${ }^{124}$ NEC's early decades, then, were defined by a struggle for the representation of Nijmegen, symbolically contested in the intense intra-city Nijmegian derby.

Even after Quick's 'relegation' to the amateur level in 1954, the perceived bond between NEC and the city of Nijmegen remained in flux. Moreover, Vitesse's team was seen to be losing touch with Arnhem. By 1971, the press worried about the derby's local character: 'Will players care about the derby this Sunday? ... If you put the two teams together, there are few true Arnhemmers and Nijmegians. ${ }^{.125}$ Not just the 'derby experience' of players mattered: there was also a crisis in derby sentiment among supporters. On average the 74 derbies between NEC and Vitesse saw 16 per cent more spectators than their other competition games. ${ }^{126}$ Yet the 1980s exhibited a near 50 per cent drop in the number of derby spectators, partly influenced by the rise of hooliganism and the decline of the level of play (see Figure 4). ${ }^{127}$ Players and journalists were disappointed ('the real derby atmosphere is a thing of the past' $)^{128}$ and sometimes even embittered ('according to our informants from Arnhem, Vitesse is bringing at least fifteen supporters to Nijmegen'). ${ }^{129}$ Recent characterizations of a 'deep sense of enmity' between NEC and Vitesse, that is 'unique to the Netherlands', ${ }^{130}$ or of the two clubs being 'everlasting rivals', ${ }^{131}$ are therefore in ways an invention of tradition.

122 PGNC, 23 Apr. 1908; Arnhemsche Courant, 9 Apr. 1907.

123 1935: 'a few thousand'; 1950: 'approximately 10,000'. De Gelderlander, 7 Oct. 1935, 11 Sept. 1950.

124 D. den Hartog, Nijmeegsche Voetbal-, Cricket-en Athletiek-Vereeniging Quick: Een Herinnering aan het Gouden Jubileum (Nijmegen, 1938), 12, 83, 120, 205.

125 De Gelderlander, 2 Dec. 1971. The increasing professionalization of Dutch football had the effect of greater mobility for players.

126 Competition matches were held from 1954. Fluctuations were partly due to extraneous circumstances such as bad weather and stadium capacity.

127 G. Valk, 'Voetbal en de Nederlandse samenleving sinds 1954', in P. Breuker and W. Joustra (eds.), Sporthistorie: Tussen Feit en Mythe (Leeuwarden, 2004), 49-58, at 55.

128 Quote from Vitesse player Roel Zaayer. De Gelderlander, 14 Apr. 1979.

129 De Gelderlander, 5 Nov. 1986.

130 Pot, De Derby, 162.

131 M. Wingens, 'Voetbaltheater Gelredome: de bouw van een Gelders Colosseum', in Verhoeven et al. (eds.), Gelderland 1900-2000, 533-8, at 534. 


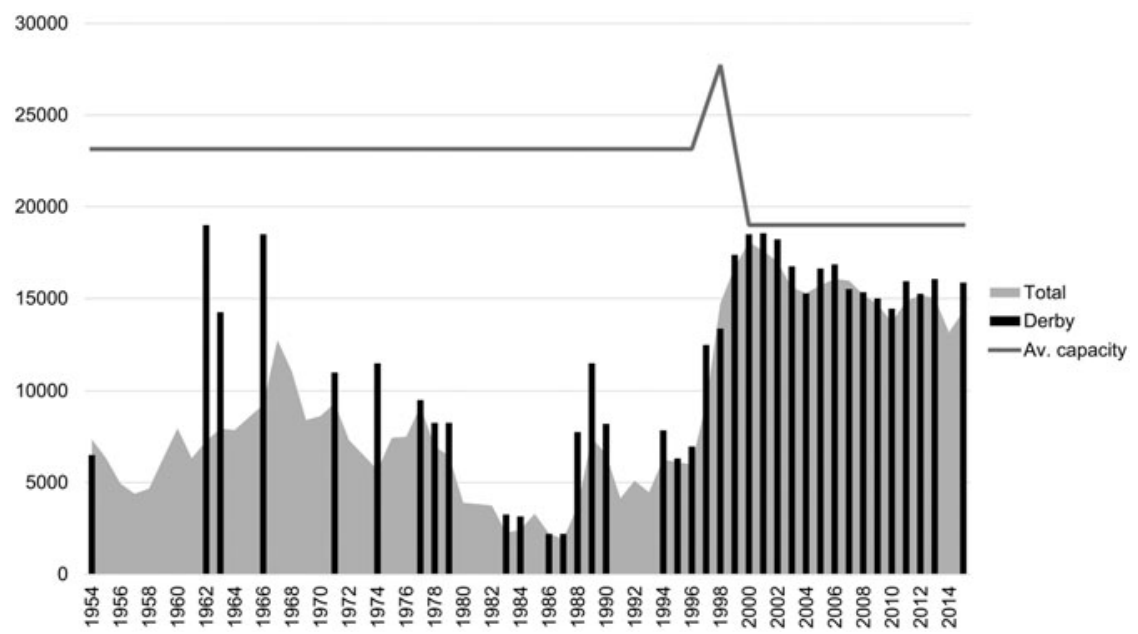

Figure 4: Average derby spectators and total average spectators for NEC and Vitesse combined

\section{Other 'place' identifications}

The convergence of club identification and city identification may seem a self-evident choice for supporters, club officials and journalists. However, football clubs are involved in many other types of 'place' identification. A club like De Graafschap from the province of Guelders evokes clear regional identification: its supporters fancy themselves 'superfarmers', projecting a rural, unpretentious club culture. ${ }^{132}$ Then there is SC Heerenveen, whose emblem is a near-exact copy of the Frisian flag. Supporters cultivate a provincial image for SC Heerenveen, even singing the official anthem of the province of Frisia before home games. Historically, Dutch clubs such as Willem II and Prinses Wilhelmina have tried to adopt a national image, deriving the club name from a member of the royal family, and donning the colours of the Dutch national flag. Internationally, even nonroyal clubs can acquire a national image, like Mohun Bagan of Kolkata, which sprang forth from (and inspired) Indian nationalism in the 1920s, or Juventus of Turin, which was known as the 'Team of Italy' in the 1930s. ${ }^{133}$ Internationally oriented clubs like Manchester United may even, in part, encourage a global image, which their rivals might call a 'placeless'

132 J. Verriet, "“Genoeglijk onderonsje" of "totale oorlog"? Regionale identificatie en Gelderse ontmoetingen in het Nederlandse voetbal', Bijdragen en Mededelingen Gelre, 107 (2016), $211-33$, at 221.

133 B. Majumdar and K. Bandyopadhyay, 'Regionalism and club domination: growth of rival centres of footballing excellence', Soccer E Society, 6 (2005), 227-56, at 244; P. Hazard and D. Gould, 'Three confrontations and a coda: Juventus of Turin and Italy', in G. Armstrong and R. Giulianotti (eds.), Fear and Loathing in World Football (Oxford, 2001), 199-219, at 209. 
image. ${ }^{134}$ Deploying the image of one's city for club identification is therefore not necessarily the most logical choice, let alone an inevitable one.

In fact, the story of NEC and Vitesse itself is marked by more than just city identification. In a 1900 meeting, Vitesse changed its club colours from Arnhem blue and white to the colours of Guelders. The club's president proclaimed that Vitesse could don the yellow and black in good conscience as it was 'one of the best clubs of Guelders' and 'set in the capital of that province'. ${ }^{135}$ On other occasions, too, Vitesse claimed the representation of the whole province of Guelders. Many years later, in 1992, the provincially backed energy company PGEM decided to sponsor Vitesse. The same year, Vitesse's board deliberated changing their name to 'Vitesse Gelderland ["Guelders"]'. ${ }^{136}$ The club also built 'Gelredome' in the 1990s: a state-of-the-art stadium, financed in part by the provincial government, named after the province of Guelders. For critics from NEC, it was further proof of the entanglement of provincial politics and Vitesse as a football club. ${ }^{137}$ 'Best not to affront localist fervour', one newspaper warned, while emotions ran high. ${ }^{138}$ To NEC supporters, the construction of Gelredome, and provocative statements from Vitesse's chairman, confirmed the negative image of Arnhemmers and Vitesse supporters. One NEC player proclaimed: 'Here [in Nijmegen] they don't appreciate the haughty tone. ${ }^{139}$

Over the last few decades, the press and other media have played an increasingly important role in the continuing enmity between the clubs - and the cities. As in other countries, through selection and presentation choices, the media created their own reality, the 'sports media reality'. ${ }^{140}$ On top of that, journalists were often supporters, and wrote commemorative books, or even became club board members. ${ }^{141}$ Newspapers also promoted Guelders rivalries: in the late 1970s, De Gelderlander even helped organize a Guelders cup. Such hype could improve sales figures, but regional newspapers like De Gelderlander also

134 T. Edensor and S. Millington, "'This is our city": branding football and local embeddedness', Global Networks, 8 (2008), 172-93, at 172.

135 Archive of Guelders, 2167 A.V.C. Vitesse, Notulen van bestuursvergaderingen, 1897-1900: Bestuursvergadering of 27 Aug. 1900.

136 NRC Handelsblad, 26 Oct. 1992.

137 Matty Verkamman and Frans van den Nieuwenhof refer to a 'curious network' of men with 'all sorts of ancillary positions'. M. Verkamman and F. van den Nieuwenhof, 50 Jaar Betaald Voetbal: De Complete Geschiedenis (Eindhoven, 2004), 377. Board members of NEC were also often involved in, or maintained good relations with, local politics.

138 De Gelderlander, 20 May 1995.

139 De Volkskrant, 19 Apr. 2003.

140 Günter Tewes, cited in: Heck, Nierhaus and Luh, 'Myth or reality', 2033.

141 This was not a new phenomenon. For example, Quick Nijmegen member (from 1905 onwards) Pieter Johannes Smink was also sports editor for various newspapers. J. Zondag, 'Vurige vaderlanders en onverschrokken Nimwegenaren: sport en militarisme in Nijmegen, ca. 1888-1918', Jaarboek Numaga, 63 (2016), 27-45, at 34. 
drew their legitimacy from the idea that Guelders was a separate cultural entity that needed its own media.

Vitesse's provincial claim had mixed success since it partly magnified existing oppositions within Guelders. Provincial identification in Guelders was and is comparatively weak. It is felt and presented as a patchwork of different cultural regions, ${ }^{142}$ and has historically been mostly a political construction. ${ }^{143}$ The perceived divide between Arnhem and Nijmegen, but also between Arnhem and other parts of Guelders, made projecting a provincial image for Vitesse difficult to achieve.

\section{Conclusion}

City identities and club identities are never completely synonymous. Yet the histories of NEC and Vitesse reveal many similarities between the two, which are often purposefully created and selectively maintained. Both NEC and Vitesse have increasingly appropriated and utilized the symbols and images of their respective cities. The process of 'othering' helped create an oppositional identity - a process that can occur for both cities and football clubs.

As the history of NEC and Vitesse shows, football clubs offer various avenues for (place-based) identification. Their perceived identities are complex and layered - they can be simultaneously urban and provincial, for example. Football club identification is dependent on the agents and circumstances involved, while the perception of the 'other' strongly shapes and limits possibilities. ${ }^{144}$

Over the past decades, the increasing mobility of the Dutch population has perhaps somewhat diminished the sense of uniqueness of the inhabitants of the two cities, which is potentially detrimental to existing mutual hostilities. The world of football, however, with its symbols and songs, its celebration of urban culture and its physical clash over regional dominance on the field, continues to provide a sphere of unreserved localism. Hence, more recently, the enmity between the football clubs has actually served to cultivate stereotypes and animosity between inhabitants of Arnhem and Nijmegen. This development affirms that a city's image is much more than a mass of shifting representations with an influence on local tourism, but that it has had - and still has - a genuine effect on the lived experiences of urban populations. Furthermore, it testifies to the historical importance of (spectator) sports for experiencing city culture and for the development of city identification.

142 Verhoeven, Het Gelderse Gevoel, 5, 8; W. Frijhoff, 'Gelderlandgevoel vroeger en nu', in M. Evers and J. Stinner (eds.), Het Hertogdom Gelre: Geschiedenis, Kunst en Cultuur tussen Maas, Rijn en IJssel (Utrecht, 2003), 494-504, at 495.

143 Frijhoff, 'Gelderlandgevoel', 504.

144 Lawrence, "'We are the boys"', 7. 
While this article provides evidence of the historical (re-)emergence of local pride and inhabitants' sense of a city's character, further studies could expand on this topic by examining the question of individual agency in greater detail. Specifically, an approach incorporating oral history would expose the everyday language which has historically constructed and modified club and city image, thereby extending insight into the interaction between the two types of representations. Such a 'bottom-up' strategy allows for examining interesting points of friction: how do people navigate between local and regional identities, both inside and outside of sports? Which historical identifications and images have existed not just between, but also within, groups of supporters? Such much-needed research would elucidate further what this article has tried to show: that football identification processes reflect and influence both a broader societal need for a place-based identity, and the desire for a coherent image of both self and the other. 